\title{
EDITORIAL
}

\section{Ongoing Tax Reforms at the EU Level: Why Trust Matters}

We are living in times where trust seems to have become the scarcest resource in the world. Information media and websites are full of stories of deceits of all kinds, whether broken promises, breaches of moral conduct or the inevitable fake news.

In this context, it should not come as a surprise that the issue of (dis)trust has become central also in international and European tax policy. At the global level, for example, many observers are indeed still debating the real objectives of the Base erosion and profit shifting (BEPS) initiative as a whole. Is it about ensuring of fairer level of taxation of multinationals, or securing the taxing rights of the OECD members against other states, in a context where economic power is drifting away from the West and towards the East? A definite answer is not likely to emerge soon. And this is partly due to the fact that the BEPS Action Plan has to be seen as a patchwork of different measures with very different origins and goals, which measures will each have different effects on the current global tax equilibrium.

The same occurs within the European Union, where one could have expected a much narrower intergovernmental cooperation. The lack of trust between Member States is certainly one of reasons for the very slow progress in the negotiations concerning the European Commission's two flagship initiatives in the area of taxation, namely the common consolidated corporate tax base and the move towards a definite of VAT regime. In both cases, indeed, the main issue seems less the adoption of common rules than the acceptance of the principle that the assessment and collection of taxes should be done by the tax administration of one Member State on behalf of one or more others.

The common consolidated corporate tax base provides for a two stages reform, namely first, the harmonization of the rules determining the taxable profits of a large European and nonEuropeans companies operating in territory of the European
Union, and subsequently, the introduction of a consolidation scheme for profits and losses and a mechanism to allocate net profits between Member States, based on predetermined criteria (assets, labour and sales), aimed at approximating the relative importance of the economic activity in the individual Member States. ${ }^{1}$ Progress in the EU Economic and Financial Affairs Council (ECOFIN) has fallen short of expectations, despite political declaration of intent - especially by large European Member States (such as France and Germany). The Commission's proposal indeed raises a number of issues, such as the personal scope of application (especially the potential coexistence of two corporate tax systems for companies below the EUR 750 million threshold) and the impact on the current corporate tax revenues of the Member States.

But beyond these technical issues lies a question of mistrust between Member States engaged in tax competition. Some Member States, especially smaller ones and/or central European states, fear that the CCCTB would reduce their corporate tax revenues. They regard it as an attempt by larger Member States to reduce their tax autonomy. On the other hand, some Member States want to protect themselves against attempts by others to divert profits generated in their territory through favourable tax measures. This well-known phenomenon of intra-EU tax competition has been going on for decades, triggering EU reactions such as the adoption of the Code of Conduct and the application of State aid rules to selective tax regimes. A more cooperative approach could be to - at least for a transitional period - to guarantee each Member State a fixed percentage of the total taxable base (based for example on population), which could constitute an incentive to collaborate, instead of negotiating on factors whose financial outcomes appear hard to predict.

In the area of value added tax, the Commission has proposed an overhaul of the current system applicable to intracommunity supplies of goods. ${ }^{2}$ The European Commission

\section{Notes}

European Commission, Proposal for a Council Directive on a Common Consolidated Corporate Tax Base (CCCTB), COM(2016) 683 final (25 Oct. 2016); European Commission, Proposal for a Council Directive on a Common Corporate Tax Base (CCCTB), COM(2016) 685 final (25 Oct. 2016).

2 European Commission, Proposal for a Council Directive Amending Directive 2006/112/EC as Regards Harmonising and Simplifying Certain Rules in the Value Added Tax System and Introducing the Definitive System for the Taxation of Trade Between Member States, COM(2017) 569 (4 Oct. 2017); European Commission, Proposal for a Council Directive Amending 
proposes radical changes aimed at abandoning the transitional system that has been in force since 1993, and moving towards a 'new' definitive regime. The current system has a very confusing feature, as it artificially decomposes a single crossborder supply (from a business perspective) into distinct taxable transactions: one exempt supply of goods in the country of origin and an intra-community acquisition of goods taxable in the country of destination. Because it enables undertakings to deduct or recover VAT without collecting it, the current system is open to fraud.

The Commission proposes a radical simplification that would suppress the intra-community acquisition and replace it with a single supply of goods, where the tax would be collected by the supplier (as it is the case for domestic supplies), but at the rate of the country of destination. The tax administration of the country of origin would then transfer the VAT revenues to the country of destination. But, alas, such a system would require a degree of cooperation and trust between domestic tax administrations which does not seem to have been reached. Some Member States are indeed extremely reluctant to accept a system where taxes would be systematically collected on behalf of others. Some invoke as an additional argument the lack of motivation for a tax administration to assess and collect a tax that would not accrue to the national budget. Sometimes, what seems to be at stake appears to be the overall efficiency or even the integrity of certain domestic tax administrations of EU Member States.

In the spirit of compromise, the European Commission tempered its proposal to allow for a specific category of taxable persons the possibility to transfer the obligation to pay the tax to the buyer (reverse charge). However, such a system would be available only to certified (i.e. trustworthy) taxable persons, which - rightly - triggered a reaction from the business community. Such a mechanism of certified taxpayers was indeed perceived as an attempt to raise the standard of compliance by imposing additional conditions for the exercise of what is currently viewed as a taxpayer prerogative, namely the right to deduct. ${ }^{3}$ This attempt to solve an issue of trust between Member State was regarded almost as proof of distrust towards business operators.
Those two important proposals from the Commission reflect a conundrum that will have to be resolved one way or another. Either there is a consensus that strengthening tax integration between Member States is in the general interest of the European Union and its components, and in such case trust in the European integration must go handin-hand with a certain level of trust between Member States, or Member States feel that the European project is not worth deepening and they accept that each State will pursue its own (perceived) self-interests even if doing so weakens its European neighbours (which may turn ultimately result in a self-harm inflicting attitude).

This lack of trust between EU tax administrations is in sharp contrast with the progress made recently in the very sensitive area of exchange of information. In light of the end of bank secrecy, the implementation of the common global standard on automatic exchange of information, not to mention within the EU, the extension of automatic exchange of information to almost to all categories of income, ${ }^{4}$ past experiences have shown that - in the right context - States are willing and capable of cooperating.

In addition to the exchange of information, EU Member States have adopted or improved various directives and regulations as regards other forms of administrative cooperation as regards extremely sensitive issues, such as joint audits ${ }^{5}$ and even tax collection on behalf of others. ${ }^{6}$ Moreover targeted initiatives within the existing EU tax cooperation framework (FISCALIS) regarding, for example, the crossing of databases, have yielded excellent results in the fight against fraud. In a globalized economy, it is an illusion to consider that tax administrations can work independently from each other. Interdependency between states must be acknowledged in order to preserve tax sovereignty.

In light of current geopolitical developments, it appears questionable whether the European Union can afford open mistrust between Member States and EU institutions, or between Member States themselves. Good relations between neighbouring countries

\section{Notes}

Directive 2006/112/EC as Regards the Introduction of the Detailed Tecbnical Measures for the Operation of the definitive VAT System for the Taxation of Trade Between Member States, $\operatorname{COM}(2018) 329$ (25 May 2018).

According to the ECJ, 'the right to deduct forms an integral part of the VAT mechanism and in principle cannot be limited'. See e.g. ES: ECJ, 21 Mar. 2000 , Joined Cases C110/98 to C-147/98, Gabalfrisa and Others v. Agencia Estatal de Administración Tributaria, ECLI:EU:C:2000:145, para. 43; BG: ECJ, 16 Feb. 2012 , Case C-118/11, Eon Aset Menidjmunt OOD v. Direktor na Direktsia 'Obzbalvane I upravlenie na izpalnenieto' - Varna pri Tsentralno upravlenie na Natsionalnata agentsia za pribodite, ECLI:EU:C:2012:97, para. 68 .

4 EU Administrative Cooperation Directive: Council Directive 2011/16/EU of 15 Feb. 2011 on administrative cooperation in the field of taxation and repealing Directive 77/ 799/EEC, OJ L64/1 (11 Mar. 2011), Art. 8.

See EU Administrative Cooperation Directive, Art. 11; Council Regulation (EU) No 389/2012 of 2 May 2012 on administrative cooperation in the field of excise duties and repealing Regulation (EC) No 2073/2004, OJ L121/1 (8 May 2012), Art. 12; Council Regulation 2010/904/EU of 7 Oct. 2010 on administrative cooperation and combating fraud in the field of VAT, OJ L268/1 (12 Oct. 2010), Arts 7 and 28, as recently amended by Council Regulation 2018/1541 of 2 Oct. 2018, OJ L259/1 (16 Oct. 2018). As for direct taxation, pilot projects have been launched, e.g. between Germany and Italy.

6 EU Tax Recovery Directive: Council Directive 2010/24/EU of 16 Mar. 2010 concerning mutual assistance for the recovery of claims relating to taxes, duties and other measures, OJ L84/1 (31 Mar. 2010). 
Intertax

have always been the cornerstone of international peace and development. And adequately adapting to the globalization of the economy necessarily implies enhancing the cooperation between tax administration within the European Union. Therefore, in tax matters Member States should not be afraid to follow Ernest
Hemingway's advice: 'The best way to find out if you can trust somebody is to trust them'.

Edoardo Traversa Professor of Tax law, Head of the Institute of European Studies, UCLouvain, Louvain-la-Neuve. Email: edoardo.traversa@uclouvain.be. 